\title{
Cytokine Gene Polymorphisms in Italian Preterm Infants: Association Between Interleukin-10 -1082 G/A Polymorphism and Respiratory Distress Syndrome
}

\author{
MARIO CAPASSO, ROSA ANNA AVVISATI, CARMELO PISCOPO, NICOLA LAFORGIA, FRANCESCO RAIMONDI, \\ FILOMENA DE ANGELIS, AND ACHILLE IOLASCON
}

\begin{abstract}
Department of Biochemistry and Medical Biotechnologies [M.C., R.A.A., C.P., A.I.], and Department of Pediatrics [F.R.], University Federico II, 80145 Naples, Italy; Department of Biomedicine of Evolutive Age [N.L.], University of Bari, 70124 Bari, Italy; Neonatal Intensive Therapy Division [F.D.A.], “A. Cardarelli” Hospital, 80131 Naples, Italy
\end{abstract}

\begin{abstract}
In this study, we determined the genotype frequencies of polymorphisms of cytokine genes and investigated their association with the risk of respiratory distress syndrome (RDS) in preterm infants. Genetic polymorphisms in the cytokines interleukin (IL)-10, IL-8, and tumor necrosis factor (TNF) $\alpha$, were studied in 342 white Italian newborns (112 without RDS, 66 prematurely born with RDS, and 164 infants born at term who were included as healthy controls). The polymorphisms were analyzed by polymerase chain reaction (PCR) restriction fragment length polymorphism (RFLP). The IL-10 mRNA levels were analyzed according to genotype by quantitative real-time PCR (QRT-PCR) in Epstein-Barr virus-transformed lymphoblastoid cell lines (EBV-LCLs) of 42 full-term healthy infants. Logistic regression analysis demonstrated the risk of RDS to be significantly lower in preterm infants with an IL-10 -1082 GG/GA genotype than in those with an AA genotype [odds ratio $(\mathrm{OR})=$ $0.48,95 \%$ confidence interval (CI): $0.24-0.95, p=0.03$ ]. QRT-PCR analyses showed that the IL-10 mRNA levels were significantly higher in 27 IL-10 -1082 GG/GA carriers compared with 15 IL-10 -1082 AA carriers $(p=0.03)$. We conclude that the IL-10 -1082 GG/GA polymorphism may have a role in RDS development in premature infants. (Pediatr Res 61: 313-317, 2007)
\end{abstract}

$\mathrm{N}^{\mathrm{e}}$ eonatal RDS is mainly caused by structural immaturity of the lung and a deficiency in pulmonary surfactant (the complex lipoprotein mixture that is produced by type II alveolar epithelial cells). The surfactant itself is made up of $90 \%$ phospholipids and $10 \%$ surfactant proteins (SPs), the latter of which include SP-A, SP-B, SP-C, and SP-D (1). Furthermore, genetic factors appear to have pivotal roles in RDS, as has been suggested by genetic studies of twins and by epidemiologic data.

The most promising candidates for this surfactant deficiency that have been identified to date lie in the genes coding for the lung-specific protein components of the pulmonary surfactant, and especially those for SP-A and SP-B. Indeed, polymorphisms in these genes have been associated with susceptibil-

Received June 27, 2006; accepted October 29, 2006.

Correspondence: Achille Iolascon, M.D., University Federico II of Naples, CEINGE Biotecnologie Avanzate s.c.ar.l., Via Comunale Margherita 482, 80145 Naples, Italy; e-mail: iolascon@dbbm.unina.it

This work was partially supported by AIRC, MURST- PRIN, Ministero Sanità, and Telethon.

DOI: $10.1203 /$ pdr.0b013e318030d108 ity to RDS (2-4), although, overall, the etiology of RDS is considered to be multifactorial and possibly multigenic.

Apart from a structural immaturity of the lung and surfactant deficiency and dysfunction, the current evidence shows unequivocally that lung inflammation is involved in RDS $(5,6)$. Cytokines may be the regulators of surfactant metabolism in the preterm infant (7), with SP-A and SP-B being involved in the maintenance of an infection-free and inflammation-free lung (8). Interstitial inflammation, as revealed by immunohistochemistry in 40 infants who died in the first week of life due to acute RDS, has been shown to be maximal at $72 \mathrm{~h}$ of age, although it had been present within hours of birth (9). Moreover, it has been shown that in preterm infants with RDS, the activation of circulating polymorphonuclear leukocytes has a role in the pathogenesis of this syndrome (10-12). In contrast, neither the mRNA nor the protein for the counterregulatory cytokine IL-10 were detectable in similar samples obtained during the first month of life compared with those obtained from infants born at term $(13,14)$. Therefore, it appears that proinflammatory and anti-inflammatory cytokines are involved in the development of RDS.

The promoter regions of a number of key cytokine genes contain polymorphisms that can directly influence cytokine production (15). Based on these observations, we hypothesized that abnormal cytokine production arising from specific polymorphisms may be involved in the development of RDS. Therefore, we undertook a case-control association study in preterm newborns to determine whether polymorphisms associated with the differential expression of IL-10, IL-8, and TNF- $\alpha$ are associated with susceptibility to RDS.

\section{PATIENTS AND METHODS}

Blood sample collection and study population. From 1999 to 2004, blood samples were obtained for genotype analysis from 342 white newborn infants from Southern Italy, after informed parental consent. The study protocol was approved by the local institutional review board. There were 178 newborn infants (112 without RDS, 66 with RDS) born prematurely $(<36$ wk of gestation) (Table 1) and 164 born at term without a family history of neonatal

Abbreviations: EBV-LCLs, Epstein-Barr virus-transformed lymphoblastoid cell lines; NF- $\mathbf{k B}$, nuclear factor $\boldsymbol{\kappa} \mathrm{B}$; QRT-PCR, quantitative real-time PCR; SNPs, single nucleotide polymorphisms; SP, surfactant protein 
Table 1. Characteristics of the infants with RDS and the premature controls

\begin{tabular}{lcc}
\hline & RDS & No RDS \\
\hline Total no. of cases & 66 & 112 \\
Females, no. & 39 & 67 \\
Males, no. & 27 & 45 \\
Gestational age, wk* & $30.4 \pm 0.29 ; 31$ & $32.3 \pm 0.22 ; 33$ \\
Birth weight, g $\dagger$ & $1437 \pm 61.08,1437$ & $1846 \pm 62.90,1700$ \\
\hline
\end{tabular}

*Mean \pm SEM; median (RDS: 24-35 wk; no RDS: 24-35 wk).

$\dagger$ Mean \pm SEM; median (RDS: 580-2575 g; no RDS, 600-3590 g).

RDS (healthy controls). None of the infants included in the analysis was transfused.

The diagnosis of RDS was made based on the reported clinical (grunting, retraction, flaring, need for supplementary $\mathrm{O}_{2}$ for $>48 \mathrm{~h}$ or the need for exogenous surfactant therapy), radiographic (diffuse reticulogranular pattern and air bronchograms), and/or pathologic (diffuse atelectasis and hyaline membranes) criteria. None of the newborn infants had had treatment with prophylactic surfactant. Also, antenatal steroid therapy was not administered to any, and none developed bronchopulmonary dysplasia (BPD).

DNA extraction. Genomic DNA was isolated from ethylenediamine tetraacetic acid anticoagulated whole blood specimens using the Wizard Genomic DNA Purification Kit (Promega Corporation, Madison, WI).

PCR. PCR amplifications of all the promoters for the IL-10, IL-8, and TNF- $\alpha$ genes were performed with the primer sequences given in Table 2 . The PCR mixtures contained $100 \mathrm{ng}$ genomic DNA, $0.1 \mathrm{mmol} / \mathrm{L}$ each of the deoxynucleotide triphosphates, 12.5 pmol each of the primers, and $1 \mathrm{U}$ of Taq polymerase (Applied Biosystems, Branchburg, NJ) in a final volume of 25 $\mu \mathrm{L}$. PCR was performed using a 9700 Gene Amp PCR System Thermal Cycler (Applied Biosystems), according to the following thermocycler conditions: $94^{\circ} \mathrm{C}$ for $2 \mathrm{~min}$, followed by 35 cycles of $94^{\circ} \mathrm{C}$ for $30 \mathrm{~s}, \mathrm{~T}_{\mathrm{A}}$ (annealing temperature) for each single nucleotide polymorphism (SNP) for $30 \mathrm{~s}$ (Table 2), and $72^{\circ} \mathrm{C}$ for $30 \mathrm{~s}$, with a final extension at $72^{\circ} \mathrm{C}$ for $7 \mathrm{~min}$.

Genotyping. The IL-10 -1082 G/A (rs1800896), IL-10 -592 A/C (rs1800872), IL-8 -251 A/T (rs4073), and TNF- $\alpha-308$ G/A (rs1800629) SNPs were genotyped by RFLP. The RFLP assays were performed in $15-\mu \mathrm{L}$ reaction volumes containing the PCR products and the specific restriction enzyme for each of the SNPs. In the presence of the IL-10 -1082 G allele, Ear I (New England Biolabs, Ipswich, MA) cut its 155-bp PCR product into two bands of 128 and $27 \mathrm{bp}$. In the presence of the IL-10 -592 A allele, RsaI (New England Biolabs) cut its 154-bp PCR product into two bands of 79 and $75 \mathrm{bp}$. Similarly, for the IL-8 -251 A allele, Mfe I (New England Biolabs) cut its 223-bp PCR product into two bands of 113 and $110 \mathrm{bp}$, and for the TNF- $\alpha$ $-308 \mathrm{G}$ allele, $N c o \mathrm{I}$ (New England Biolabs) cut the 224-bp PCR product into two bands of 208 and $16 \mathrm{bp}$. These digestion products were visualized in $3.5 \%$ agarose gels that were stained with ethidium bromide. This genotyping by RFLP was also confirmed by automated DNA sequencing.

Generation of cell lines. EBV-LCLs were established by culturing peripheral blood mononuclear cells in the presence of $100 \mu \mathrm{g} / \mathrm{mL}$ cyclosporine (Sigma Chemical Co. Aldrich, Milan, Italy) with the EBV supernatant harvested from the B95-8 cell line (German Collection of Microorganisms and Cell Cultures, Braunschweig, Germany). The EBV-LCLs were maintained in RPMI 1640 medium supplemented with $20 \%$ fetal bovine serum, 2 $\mathrm{mmol} / \mathrm{L}$ glutamine, $20 \mathrm{U} / \mathrm{mL}$ penicillin, and $0.2 \mathrm{mg} / \mathrm{mL}$ streptomycin (CELBIO, Pero, Milan, Italy).

RNA isolation and reverse transcription. Total cellular RNA was extracted from the cultured cells by the guanidinium isothiocyanate method, using the TRIzol reagent (16). All the reverse transcriptase reactions were performed using SuperScript II RNase H-Reverse Transcriptase (Invitrogen, San Diego, CA), with oligo-dT priming, according to the manufacturer's instructions.

QRT-PCR analysis. QRT-PCR was performed using the SYBER green method, with an Applied Biosystem Model 7900HT Sequence Detection System. The primers were designed with the Primer Express 2.0 program (Applied Biosystems), and the sequences were as follows: IL-10 (forward) 5'-ACCTGCCTAACATGCTTCGAG-3', (reverse) 5'-TGTCCAGCTGATCCTTCATTTG-3', and $\beta$-actin (forward) 5'-CGTGCTGCTGACCGAGG-3,' (reverse) $5^{\prime}$-GAAGGTCTCAAACATGATCTGGGT-3'. All the PCRs were performed in duplicate. The relative gene expressions were calculated using the $2^{(-\Delta \mathrm{Ct})}$ method, in which Ct indicates the cycle threshold, the fractional cycle number at which the fluorescent signal reaches the detection threshold. $\beta$-Actin was used as the internal control (17). The $\Delta \mathrm{Ct}$ was calculated using the differences in the mean Ct between the IL-10 gene and the internal controls.

Statistical analysis. A comparison of the genotypic and allelic frequencies between the groups was performed using the $\chi^{2}$ test with Yates correction for the specific case of $2 \times 2$ tables. Multivariate logistic regression analysis was performed to investigate whether heterozygosity or homozygosity for particular alleles could explain the risk of RDS. ORs of the genotypic variables and confounders for RDS (gestational age at birth, gender) included in the analysis were estimated using a logistic regression model, where the presence or absence of RDS was the dependent variable. For QRT-PCR, the data were presented as median and mean \pm standard error of the mean (SEM). The significance of the relative gene expression differences was determined using the Mann-Whitney $U$ test. The Shapiro-Wilk test was used for testing normality. Statistical significance was established at $p=0.05$.

\section{RESULTS}

Allele and genotype frequencies. DNA samples from 64 prematurely born infants with RDS and 112 premature control infants were available for the genotype analysis of the selected polymorphisms. Their clinical data are given in Table 1 .

Table 3 summarizes our findings on the allelic and genotypic distributions of these cytokine gene SNPs in all the samples collected. The Hardy-Weinberg equilibrium was checked in all three of the groups (RDS, no RDS, and healthy controls) by $\chi^{2}$ tests for each polymorphism. All the markers were in Hardy-Weinberg equilibrium.

The allele and genotype frequencies of the IL-10 -592 A/C, IL-8 -251 A/T, and TNF- $\alpha-308$ G/A polymorphisms were not significantly different between the two preterm infant groups (Table 3). The genotypic and allelic distributions of the polymorphism at position -1082 of IL-10 were instead significantly different in the preterm infants with RDS compared with the preterm infants without RDS ( $p=0.03$ and $p=0.02$, respectively) (Table 3 ). To better define the independent contributions of the heterozygosity and homozygosity for the $\mathrm{G}$ allele to genetic susceptibility to RDS, we performed multivariate logistic regression analysis. When the genotypic

Table 2. Characteristics of the cytokine gene polymorphisms, primer sequences and PCR conditions

\begin{tabular}{|c|c|c|c|c|c|}
\hline Gene & $\begin{array}{l}\text { Promoter position } \\
\text { of the polymorphism }\end{array}$ & Allele & Phenotype & Primer sequences $5^{\prime}-3^{\prime}$ & $\mathrm{T}_{\mathrm{A}}\left({ }^{\circ} \mathrm{C}\right)$ \\
\hline \multirow[t]{2}{*}{ IL-10 } & -1082 & G & High & F: CCAGGTAGAGCAACACTCCT & 55 \\
\hline & & A & Low & R: CTCTTACCTATCCСТАСТTCCGC & \\
\hline IL-10 & & A & Low & R: ATGAGGGGGTGGGCTAAATA & \\
\hline \multirow[t]{2}{*}{ IL-8 } & -251 & A & High & F: TATGCCATTAAAAGAAAATCATCCAT & 60 \\
\hline & & $\mathrm{T}$ & Low & R: TCAAATACGGAGTATGACGAAAGTTT & \\
\hline
\end{tabular}

$\mathrm{T}_{\mathrm{A}}$ : Annealing temperature for each individual SNP; F: forward; R: reverse. 
Table 3. Absolute allele and genotype frequencies in white newborns in southern Italy

\begin{tabular}{|c|c|c|c|c|}
\hline \multirow[b]{2}{*}{ Geneticpolymorphisms } & \multicolumn{2}{|c|}{ Prematurely born } & \multirow{2}{*}{$\begin{array}{c}\text { Full term } \\
\text { Controls* } \\
(\mathrm{n}=164), \\
\text { No. }(\%)\end{array}$} & \multirow[b]{2}{*}{$p \dagger$} \\
\hline & $\begin{array}{c}\text { No RDS } \\
(n=112), \\
\text { No. }(\%)\end{array}$ & $\begin{array}{c}\text { RDS } \\
(n=64), \\
\text { No. }(\%)\end{array}$ & & \\
\hline \multicolumn{5}{|l|}{ IL-10-1082 G/A } \\
\hline \multicolumn{5}{|l|}{ Genotypes } \\
\hline $\mathrm{AA}$ & $38(33.9)$ & $35(54.7)$ & $73(44.5)$ & 0.03 \\
\hline GA & $58(51.8)$ & $23(35.9)$ & $66(40.2)$ & \\
\hline GG & $16(14.3)$ & $6(9.4)$ & $25(15.2)$ & \\
\hline \multicolumn{5}{|l|}{ Alleles } \\
\hline A & $134(59.8)$ & $93(72.7)$ & $212(64.6)$ & 0.02 \\
\hline $\mathrm{G}$ & $90(40.2)$ & $35(27.3)$ & $116(35.4)$ & \\
\hline \multicolumn{5}{|l|}{ IL-10 -592 A/C } \\
\hline \multicolumn{5}{|l|}{ Genotypes } \\
\hline AA & $9(8.0)$ & $5(7.8)$ & $13(7.9)$ & 0.99 \\
\hline $\mathrm{AC}$ & $53(47.3)$ & $30(46.9)$ & $74(45.1)$ & \\
\hline $\mathrm{CC}$ & $50(44.6)$ & $29(45.3)$ & $77(47.0)$ & \\
\hline \multicolumn{5}{|l|}{ Alleles } \\
\hline A & $71(31.7)$ & $40(31.3)$ & $100(30.5)$ & 0.97 \\
\hline $\mathrm{C}$ & $153(68.3)$ & $88(68.7)$ & $228(69.5)$ & \\
\hline \multicolumn{5}{|l|}{ TNF- $\alpha-308$ G/A } \\
\hline \multicolumn{5}{|l|}{ Genotypes } \\
\hline AA & $2(1.8)$ & $2(3.1)$ & $0(0.0)$ & 0.71 \\
\hline GA & $16(14.3)$ & $7(10.9)$ & $27(16.5)$ & \\
\hline GG & $94(83.9)$ & $55(85.9)$ & $137(83.5)$ & \\
\hline \multicolumn{5}{|l|}{ Alleles } \\
\hline A & $20(8.9)$ & $11(8.6)$ & $27(8.2)$ & 0.93 \\
\hline $\mathrm{G}$ & $204(91.1)$ & $117(91.4)$ & $301(91.8)$ & \\
\hline \multicolumn{5}{|l|}{ IL-8 $-251 \mathrm{~A} / \mathrm{T}$} \\
\hline \multicolumn{5}{|l|}{ Genotypes } \\
\hline $\mathrm{AA}$ & $17(15.2)$ & $11(17.2)$ & $36(22.0)$ & 0.23 \\
\hline $\mathrm{TA}$ & $53(47.3)$ & $37(57.8)$ & $74(45.1)$ & \\
\hline $\mathrm{TT}$ & $42(37.5)$ & $16(25.0)$ & 54 (32.9) & \\
\hline \multicolumn{5}{|l|}{ Alleles } \\
\hline A & 87 (38.8) & $59(46.1)$ & $146(44.5)$ & 0.22 \\
\hline $\mathrm{T}$ & $137(61.2)$ & $69(53.9)$ & $182(55.5)$ & \\
\hline
\end{tabular}

* The genotype and allele frequencies of healthy controls were not significantly different compared with the non-RDS patients.

$\dagger$ Significance of difference between non-RDS and RDS groups.

variables (classified into two categories: AA and GG or GA) were included in the model, after the correction for gestational age (number of weeks) and gender, they were seen to be independently associated with RDS. The data showed that the risk of RDS was significantly lower in preterm infants with the GG and GA genotypes than with those with the AA genotype $(\mathrm{OR}=0.48 ; 95 \%$ CI: $0.24-0.95 ; p=0.03)$. This correction for gestational age and gender in the multivariate analysis excluded the possibility that the association of the IL-10 -1082 GG/GA genotype with a lower risk of RDS was influenced by different gestational age and sex distributions among the RDS and non-RDS groups. None of these polymorphisms (IL-10 -1082 G/A, IL-10 -592 A/C, IL-8 -251 A/T, TNF- $\alpha-308$ G/A) differed significantly in allele or genotype distribution between the control premature $(n=$ $112)$ and term $(n=164)$ infants.

Differential IL-10 gene expression associated with the -1082 G/A polymorphism. To determine whether any variant of IL-10 -1082 G/A could affect IL-10 expression, we established EBV-LCLs from the peripheral blood mononuclear

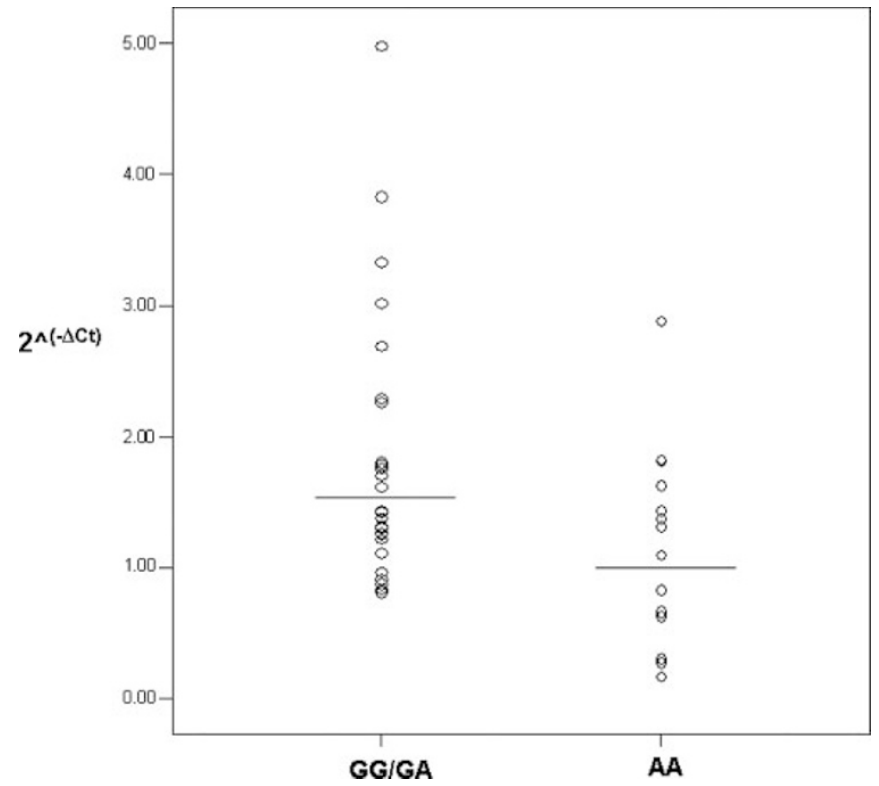

Figure 1. Differential IL-10 gene expression associated with the -1082 G/A polymorphism in EBV-LCLs in peripheral blood mononuclear cells of 42 full-term healthy infant controls: 15 with the AA genotype and 27 with the GG/GA genotype (20 with GA, seven with GG). QRT-PCR analysis of IL-10 gene expression showed significant increases in the GG/GA subjects (median, 1.43; mean $1.81 \pm 0.19$ ), with respect to the AA subjects (median, 1.01; mean, $1.13 \pm 0.19)(p=0.03)$. The $y$ axis of $2^{(-\Delta \mathrm{Ct})}$ represents the relative gene expression of IL-10. The $\Delta \mathrm{Ct}$ values were calculated using the differences in the mean $\mathrm{Ct}$ values between the IL-10 gene and the internal control of $\beta$-actin.

cells of 42 full-term healthy infant controls: 15 with the AA genotype, and 27 with the GG/GA genotype (seven with the GG and 20 with the GA genotype). The QRT-PCR analyses were then applied, which showed that IL-10 mRNA levels were significantly higher in the IL-10 -1082 GG/GA carriers $(n=27$; median, 1.43 ; mean, $1.81 \pm 0.19)$ than in the IL-10 -1082 AA carriers $(n=15$; median, 1.01 ; mean, $1.13 \pm 0.19)$ $(p=0.03)$ (Fig. 1). The $2^{(-\Delta \mathrm{Ct})}$ values of the GG/GA group were not normally distributed, as seen by the Shapiro-Wilk test ( $p<0.05$ for GG/GA group; $p=0.41$ for AA group); we therefore used a nonparametric test (Mann-Whitney $U$ ) to compare the mRNA levels between these two groups.

\section{DISCUSSION}

Here, we investigated the cytokine IL-10 -1082 G/A, IL-10 $-592 \mathrm{~A} / \mathrm{C}$, IL- $8-251 \mathrm{~A} / \mathrm{T}$, and TNF- $\alpha-308 \mathrm{G} / \mathrm{A}$ gene promoter polymorphisms and determined their relationships to the occurrence of RDS in a population of preterm newborns in southern Italy. The data show that the IL-10 -592, IL-8 -251 and TNF- $\alpha-308$ genotypes did not differ significantly between the RDS and non-RDS groups. In contrast, significant differences were seen for the frequencies of the IL-10 -1082 genotypes and alleles. Furthermore, our results show that the IL-10 -1082 GG/GA genotype carriers were significantly more frequent in the non-RDS group than in the RDS group after correction for gestational age and sex. The comparison between the control preterm and term neonates showed that there were no differences in the frequencies of the same 
polymorphisms, indicating that prematurity is unlikely to be a confounder in our analyses.

IL-10 is an important immunoregulatory cytokine that is mainly produced by monocytes, macrophages, $\mathrm{T}$ cells, and $\mathrm{B}$ cells. It controls the inflammatory processes by suppressing the expression of proinflammatory cytokines, chemokines, adhesion molecules, and antigen-presenting and costimulatory molecules in monocytes/macrophages, neutrophils, and $\mathrm{T}$ cells (18). Several studies of complex diseases have indicated a major role for IL-10 in chronic inflammatory disorders that are characterized by the predominance of cytokines such as IL-1, IL-6, IL-8, IL-12, and TNF. These included psoriasis, Crohn's disease, multiple sclerosis, and rheumatoid arthritis $(18,19)$.

The precise mechanisms involved in the regulation of IL-10 production remain to be determined, although inherited factors appear to have important roles. A difference in IL-10 secretion in association with a SNP in the -1082 position of the gene promoter has been demonstrated. In particular, an association of the $-1082 \mathrm{G}$ allele with a high IL-10-producing ability has been shown, through assessments of both mRNA and protein (20-22). Here, we see that EBV-LCLs from full-term healthy infant controls carrying the IL-10 $-1082 \mathrm{G}$ allele (the IL-10 -1082 GG/GA genotypes) have increased IL-10 mRNA levels compared with those with an IL-10 -1082 AA genotype. The IL-10 -1082 G/A SNP is located within an Ets binding site. The $-1082 \mathrm{~A}$ allele confers a higher binding affinity to the transcription factor PU.1, which inhibits gene expression and leads to decreased IL-10 expression in individuals carrying this allele (23); thus, it is plausible that the IL-10 -1082 GG and GA genotypes also have high expression rates in the premature lung.

To date, there have been a few studies that have documented the differences in IL-10 detection and quantities in premature infants with RDS, in terms of whether they develop BPD $(13,24,25)$. However, there have been no previous studies that have looked for an association between genetic susceptibility to neonatal lung disease and IL-10 gene polymorphisms. Only in a study by Yanamandra et al. (26) was it possible to show that the IL-10 -1082 A allele (for lower IL-10 production) had a minor effect on the combined outcome of death or BPD. Therefore, it appears that low IL-10 production and the consequent increase in the proinflammatory cytokines are associated with a favorable outcome for BPD. This hypothesis is in contrast with previous studies that have demonstrated that multiple proinflammatory and chemotactic factors are present in the air spaces of ventilated preterm infants and that these factors are found in higher concentrations in the air spaces of infants who subsequently develop BPD. Factors such as macrophage inflammatory protein- 1 and IL-8 persist in the air spaces, and counterregulatory cytokines, such as IL-10, may be decreased, resulting in unregulated and persistent inflammation $(27,28)$. We show that heterozygosity or homozygosity for the IL-10 $-1082 \mathrm{G}$ allele (for higher IL-10 production) is more frequent among infants without RDS, suggesting a protective role in this pathology. Although contrary to the data of Yanamandra et al. (26), our data are consistent with previous findings that have seen no decrease in or absence of IL-10 expression at the levels of mRNA and protein in cells obtained through bronchoalveolar lavage from lungs of premature neonates with hyaline membrane disease $(13,14)$. Moreover, the development of recombinant IL-10 as a potential anti-inflammatory agent in the treatment of hyaline membrane disease has been suggested (29). The IL-10 -1082 GG genotype has been reported to be a protecting factor against other pulmonary diseases, such as acute RDS and active tuberculosis $(30,31)$. However, further studies are needed to confirm that our observations do indeed apply to other patient populations. Other SNPs in the promoter region of the IL-10 gene may also be associated with increased or decreased IL-10 production. For instance, recent studies have indicated that the T-3575A, G-2849A, and C-2763A SNPs are associated with susceptibility to systemic lupus erythematosus (32), and leprosy and disease severity in leprosy (33). It is therefore important to investigate the roles of these and other SNPs and haplotypes in RDS in future studies.

Surfactant deficiency in preterm infants leads to RDS, although some of the available data also suggest participation of local inflammation and its interaction with the surfactant system. The SPs SP-A and SP-D are important in the innate host defense system against pathogenic microorganisms and in the modulation of acute inflammation (8). It has been demonstrated that when IL- $1 \alpha$ is given intra-amniotically to immature rabbit or sheep, it increases SP-A and SP-B mRNA levels and decreases the severity of RDS after premature birth $(34,35)$. Additionally, another study revealed that IL- $1 \alpha$ has a biphasic influence on the expression of the SPs, thus increasing SP-A and SP-B mRNA in early premature lung and decreasing the expression SP-B and SP-C in the transitional and mature lung (36). Watterberg et al. (37) noted that in early premature infants with intrauterine infection, the incidence of RDS is lower than that expected based on their very early birth. Hallak and Bottoms (38) showed that premature infants who were more mature than in the series presented by Watterberg et al. (37) had an increased incidence of RDS in intrauterine infection. Moreover, circulating polymorphonuclear leukocytes are activated in preterm infants with RDS, and this appears to have a role in pathogenesis, with leukocyte activation present only $2 \mathrm{~h}$ after birth (10-12). We hypothesize that due to a specific genotype of IL-10 -1082 G/A polymorphism in our population study, the low proinflammatory cytokine levels correlate with a lower risk of RDS. This hypothesis is supported by a number of studies demonstrating that IL-10 inhibits nuclear factor- $\kappa \mathrm{B}$ (NF- $\kappa \mathrm{B})$ activity $(39,40)$. Many of the proinflammatory cytokines and costimulatory proteins that have been demonstrated to be suppressed by IL-10 are known to be regulated by the NF- $\kappa \mathrm{B}$ transcription factor. Thus, it has been seen that patients with RDS had an increased expression of NF- $\kappa \mathrm{B}$ in their alveolar macrophages on d 2 and 4 , compared with a control group, and that the IL- $1 \beta$ and IL- 8 levels were closely correlated to NF- $\kappa$ B expression (41). Therefore, we believe that the IL-10 -1082 GG/GA genotype is potentially associated with a decreased NF- $\kappa \mathrm{B}$ activity that results in the down-expression of proinflammatory cytokines. Further studies need to be performed to address this hypothesis. 
In conclusion, this study suggests that the IL-10 -1082 GG/GA genotype is associated with a decreased risk of RDS. This association is biologically acceptable because the $G$ allele has been associated with increased IL-10 production and decreased production of proinflammatory cytokines, which have been associated with increased severity of RDS in preterm infants. Our results may contribute toward the development of new therapies.

Acknowledgments. The authors thank the parents of the newborn infants who agreed to participate in this project.

\section{REFERENCES}

1. Pryhuber GS 1998 Regulation and function of pulmonary surfactant protein B. Mol Genet Metab 64:217-228

2. Haataja R, Ramet M, Martilla R, Hallman M 2000 Surfactant proteins A and B as interactive genetic determinants of neonatal respiratory distress syndrome. Hum Mol Genet 9:2751-2760

3. Haataja R, Martilla R, Uimar P, Lofgren J, Ramet M, Hallman M 2001 Respiratory distress syndrome: evaluation of genetic susceptibility and protection by transmission disequilibrium test. Hum Genet 109:351-355

4. Rämet M, Haataja R, Marttila R, Floros J, Hallman M 2000 Association between the surfactant protein A (SP-A) gene locus and respiratory-distress syndrome in the Finnish population. Am J Hum Genet 66:1569-1579

5. Copland IB, Post M 2002 Understanding the mechanisms of infant respiratory distress and chronic lung disease. Am J Respir Cell Mol Biol 26:261-265

6. Speer CP, Ruess D, Harms K, Herting E, Gefeller O 1993 Neutrophil elastase and acute pulmonary damage in neonates with severe respiratory distress syndrome. Pediatrics 91:794-799

7. Wispe JR, Clark JC, Warner BB, Fajardo D, Hull WE, Holtzman RB, Whitsett JA 1990 Tumor necrosis factor-alpha inhibits expression of pulmonary surfactant protein. J Clin Invest 86:1954-1960

8. Wright JR 1997 Immunomodulatory functions of surfactant. Physiol Rev 77: 931-962

9. Murch SH, Costeloe K, Klein NJ, MacDonald TT 1996 Early production of macrophage inflammatory protein-1 alpha occurs in respiratory distress syndrome and is associated with poor outcome. Pediatr Res 40:490-497

10. Brus F, Vanoeveren W, Okken A, Oetom SB 1996 Activation of circulating polymorphonuclear leukocytes in preterm infants with severe idiopathic respiratory distress syndrome. Pediatr Res 39:456-463

11. Ferreira PJ, Bunch TJ, Albertine KH, Carlton DP 2000 Circulating neutrophil concentration and respiratory distress in premature infants. J Pediatr 136:466-472

12. Nupponen I, Pesonen E, Andersson S, Makela A, Turnen R, Kautiainen H 2002 Neutrophil activation in preterm infants who have respiratory distress syndrome. Pediatrics 110:36-41

13. Jones CA, Cayabyab RG, Kwong KY, Stotts C, Wong B, Hamdan H 1996 Undetectable interleukin (IL)-10 and persistent IL-8 expression early in hyaline membrane disease: a possible developmental basis for the predisposition to chronic lung inflammation in preterm newborns. Pediatr Res 39:966-975

14. Kwong KY, Jones CA, Cayabyab R 1998 Differential regulation of IL-8 by IL-1beta and TNFalpha in hyaline membrane disease. J Clin Immunol 18:71-80

15. Bidwell J, Keen L, Gallagher G, Kimberly R, Huizinga T, McDermott MF, Oksenberg J, McNicholl J, Pociot F, Hardt C, D'Alfonso S 2001 Cytokine gene polymorphism in human disease: on-line databases. Genes Immun 2:61-70

16. Chomczynski P, Sacchi N 1987 Single-step method of RNA isolation by acid guanidinium thiocyanate-phenol-chloroform extraction. Anal Biochem 162:156-159

17. Livak KJ, Schmitteng TD 2001 Analysis of relative gene expression data using real-time quantitative PCR and the 2(-delta delta C(T)). Methods 25:402-408

18. Asadullah K, Sterry W, Volk HD 2003 Interleukin-10 therapy-review of a new approach. Pharmacol Rev 55:241-269
19. Hajeer AH, Lazarus M, Turner D, Mageed RA, Vencovsky J, Sinnott P, Hajeer AH, Lazarus M, Turner D, Mageed RA, Vencovsky J, Sinnott P, Hutchinson IV, Ollie WE 1998 IL10 gene promoter polymorphisms in rheumatoid arthritis. Scand J Rheumatol 27:142-145

20. Turner DM, Williams DM, Sankaran D, Lazarus M, Sinnott PJ, Hutchinson IV 1997 An investigation of polymorphism in the interleukin-10 gene promoter. Eur J Immunogenet 24:1-8

21. Eskdale J, Gallagher G, Verweij CL, Keijsers V, Westendorp RG, Huizinga TW 1998 Interleukin 10 secretion in relation to human IL-10 locus haplotypes. Proc Nat Acad Sci U S A 95:9465-9470

22. Suarez A, Castro P, Alonso R, Mozo L, Gutierrez C 2003 Interindividual variation in constitutive interleukin-10 messenger RNA and protein levels and their association with genetic polymorphisms. Transplantation 75:711-717

23. Reuss E, Fimmers R, Kruger A, Becker C, Rittner C, Hohler T 2002 Differential regulation of interleukin-10 production by genetic and environmental factors - a twin study. Genes Immun 3:407-413

24. Huang HC, Yang MY, Huang CB, Yang KD 2000 Profiles of inflammatory cytokines in bronchoalveolar lavage fluid from premature infants with respiratory distress disease. J Microbiol Immunol Infect 33:19-24

25. Jonsson B, Li YH, Noack G, Brauner A, Tullus K 2000 Downregulatory cytokines in tracheobronchial aspirate fluid from infants with chronic lung disease of prematurity. Acta Paediatr 89:1375-1380

26. Yanamandra K, Boggs P, Loggins J, Baier RJ 2005 Interleukin-10 -1082 G/A polymorphism and risk of death or bronchopulmonary dysplasia in ventilated very low birth weight infants. Pediatr Pulmonol 39:426-432

27. Groneck P, Speer CP 1995 Inflammatory mediators and bronchopulmonary dysplasia. Arch Dis Child Fetal Neonatal Ed 73:F1-F3

28. Jobe AH, Bancalari E 2001 Bronchopulmonary dysplasia. Am J Respir Crit Care Med 163:1723-1729

29. Kwong KY, Jones CA, Cayabyab R 1998 The effects of IL-10 on proinflammatory cytokine expression (IL-1beta and IL-8) in hyaline membrane disease (HMD). Clin Immunol Immunopathol 88:105-113

30. Gong MN, Thompson BT, Williams PL, Zhou W, Wang MZ, Pothier L, Christiani DC 2006 Interleukin-10 polymorphism in position -1082 and acute respiratory distress syndrome. Eur Respir J 27:674-681

31. Henao MI, Montes C, Paris SC, Garcia LF 2006 Cytokine gene polymorphisms in Colombian patients with different clinical presentations of tuberculosis. Tuberculosis (Edinb) 86:11-19

32. Chong WP, Ip WK, Wong WH 2004 Association of interleukin-10 promoter polymorphisms with systemic lupus erythematosus. Genes Immun 5:484-492

33. Moraes MO, Pacheco AG, Schonkeren JJ 2004 Interleukin-10 promoter singlenucleotide polymorphisms as markers for disease susceptibility and disease severity in leprosy. Genes Immun 5:592-595

34. Bry K, Lappalainen U, Hallman M 1997 Intraamniotic interleukin-1 accelerates surfactant protein synthesis in fetal rabbits and improves lung stability after premature birth. J Clin Invest 99:2992-2999

35. Emerson GA, Bry K, Hallman M, Jobe AH, Wada N, Ervin MG, Ikegami M 1997 Intra-amniotic interleukin-1 alpha treatment alters postnatal adaptation in premature lambs. Biol Neonate 72:370-379

36. Glumoff V, Vayrynen O, Kangas T, Hallman M 2000 Degree of lung maturity determines the direction of the interleukin-1-induced effect on the expression of surfactant proteins. Am J Respir Cell Mol Biol 22:280-288

37. Watterberg KL, Demers LM, Scott SM, Murphy S 1996 Chorioamnionitis and early lung inflammation in infants in whom bronchopulmonary dysplasia develops. Pediatrics $97: 210-215$

38. Hallak M, Bottoms SF 1993 Accelerated pulmonary maturation from preterm premature rupture of membranes: a myth. Am J Obstet Gynecol 169:1045-1049

39. Schottelius AJ, Mayo MW, Sartor RB, Baldwin AS Jr 1999 Interleukin-10 signaling blocks inhibitor of kappaB kinase activity and nuclear factor kappaB DNA binding. J Biol Chem 274:31868-31874

40. Wang P, Wu P, Siegel MI, Egan RW, Billah MM 1995 Interleukin (IL)-10 inhibits nuclear factor kappa B (NF kappa B) activation in human monocytes. IL-10 and IL-4 suppress cytokine synthesis by different mechanisms. J Biol Chem 270:9558-9563

41. Cao L, Liu C, Cai B, Jia X, Kang L, Speer CP, Sun B 2004 Nuclear factor-kappa B expression in alveolar macrophages of mechanically ventilated neonates with respiratory distress syndrome. Biol Neonate 86:116-123 